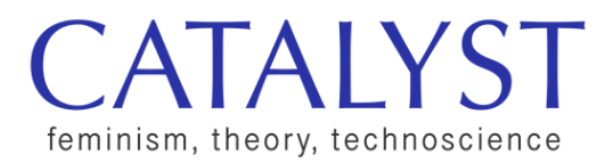

\title{
The Space between Us: Network Gaps, Racism, and the Possibilities of Living in/Difference
}

\author{
Wendy Hui Kyong Chun \\ Simon Fraser University \\ ddi_lab@sfu.ca
}

\section{Abstract}

This article explores how the "gaps" that structure networks and communities enclose and preserve "racialized others," whom they seem to expel: from Black residents in US biracial housing projects to Japanese and Japanese Americans in World War II internment camps. It also calls for an embrace of ambi-valent neighbors to render these undead spaces into vibrant, if in/different, modes of inhabitation.

\section{Keywords}

networks; sentiment analysis; internment camps; segregation; COVID-19 and anti-Asian hate

"Anti-Asian" violence soared during the first waves of the 2020 COVID-19 pandemic. From mid-March 2020 to the end of February 2021, 3,795 "anti-Asian hate incidents" were reported to the US Stop AAPI Hate reporting center; north of the US border in the Canadian province of British Columbia, "anti-Asian" hate crimes increased by 717 percent in 2020 (Jeung et al. 2021; Manojlovic 2021). These incidents ranged from lethal physical attacks on elderly persons to strangers spitting on Asian-looking passersby. As many commenters and researchers noted, this dramatic increase in violence corresponded to a former US president's accusations that the Chinese were responsible for "kung flu" and for undermining the US economy (see, e.g., Ho 2021; Sprunt 2021). Destroying, or at the very least vilifying, China was part of "Making America Great Again." As many 
also stressed, this rhetoric and violence did not exist in isolation: they formed and evolved in relation to anti-Black and anti-Indigenous racism. And they were not new: they are the latest forms of centuries-old "yellow peril" racism, which includes exclusion laws, internments, lynchings, and theft. Asian Americansregardless of their ethnicity, citizenship status, and natality-have been at best ambivalently assimilated in the United States and Canada (see, e.g., Palumbo-Liu 1999; Le 2019; De Leon 2021).Tellingly, the label "anti-Asian hate" erases the term "Asian American" and its political stakes: "Asian American" was inspired by the US civil rights and Black Power movements and responds to discrimination that refuses to acknowledge individual or ethnic differences through solidarity (Shimakawa 2002).

This article starts from responses to the "crisis of uncertainty" provoked by the first wave of the COVID-19 pandemic in 2020 to outline how segregation and the desire to "contain others" underlies network fundamentals. Drawing from and expanding upon my examination of homophily - the axiom that similarity breeds connection-in Discriminating Data (Chun 2021), I explore how the "gaps" that structure networks and communities enclose and preserve "racialized others," whom they seem to expel: from Black residents in US biracial housing projects to Japanese and Japanese Americans in World War II internment camps. The article ends by calling for an embrace of ambi-valent neighbors to render these undead spaces into vibrant, if in/different, modes of inhabitation.

\section{Resolving Uncertain Connections}

The first waves of the COVID-19 pandemic personified the stakes and consequences of connection, polarization, infrastructures, and habits. To many, the world had turned upside down and the unimaginable had become possible: "socialism" and extensive surveillance within the US; a retracting Chinese economy and oil prices below zero dollars; the invocation of Cold War "shelter-inplace" ordinances; and KKK hoods worn as "protective masks" in California (Ambrose 2020; Associated Press 2020; Elliott 2020; Martineau 2020; Žižek 2020). This crisis highlighted and augmented already existing inequalities: from white-collar workers seeking the "perfect" gadget for working from home to the mainly non-white and poorly paid "essential" workers balancing daily financial and medical risks (CDC 2020).

The uncertainty-and overwhelming need to act-undermined any simple division between science and politics, knowledge and action. The science itself, after all, was uncertain. Many of the first guidelines presumed similarities between SARS Cov-2 and SARS Cov-1, which were later proven wrong, such as the period when a person is most infectious: in SARS Cov-1, the infection period is while one is most symptomatic; for SARS Cov-2, it is just beforehand (Rancaniello et al. 2020). Early knowledge of COVID-19-as of all new diseases-was mainly correlational, with mechanistic-genetic explanations lagging behind observation and comparison. 
For example, SARS Cov-2 was presumed not to be airborne because it was initially far less contagious than airborne diseases such as measles. In desperation turned pharmaceutical opportunity, drugs were approved, such as remdesivir, which did not significantly affect mortality rates and was discontinued early in clinical trials because of debilitating side effects (Wang et al. 2020). Further, due to the initial dearth and poor quality of tests and testing materials, the scope of the pandemic - the number or proportion of "susceptibles," "infected," and "recovereds" - was unknown. It was even unclear if "recovereds" were immune, or for how long (Chappell 2020; Patel 2020).

This uncertainty, however, did not undermine science or politics: it drove research and made political decisions both difficult and necessary. Correlations and probabilities intersected this cloud of uncertainty. They could guide decisions, even if they could not guarantee them, for the pandemic and its "cures" confronted us with responsibility in the strongest sense of the word. As human rights researcher Thomas Keenan has argued, we face responsibility not when we make decisions by following guidelines and rules but when we desperately want to but cannot because the situation falls outside the norm. We face responsibility "when we do not know exactly what we should do, when the effects and conditions of our actions can no longer be calculated, and when we have nowhere else to turn, not even back onto our 'self'"' $(1997,2)$. Not even back onto our selfbecause at these moments we realize that the individual is, to use philosopher Jean-Luc Nancy's evocative term, "the residue of the dissolution of community" $(1991,3)$. This uncertain response, however, did and does not guarantee good ethical or political decisions. As political geographer Louise Amoore has shown in her analysis of the use of correlation and derivatives to envision to "low probability, high impact" events, these responses can often lead to a problematic "politics of possibility" focused around "managing" corporate and security risks $(2013,75)$. 
HM Government

\section{STAY HOME}

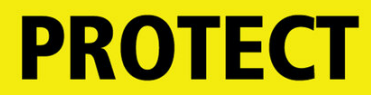

THE NHS

\section{SAVE LIVES}

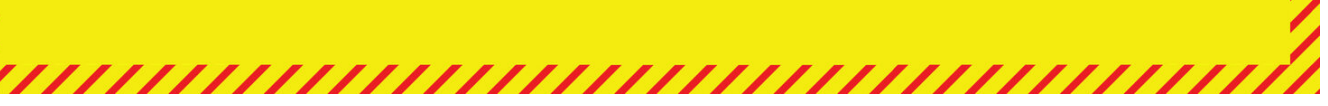

Figure 1: The UK's NHS slogan during first Wave of COVID-19.

Tx Lt Gov Dan Patrick says grandparents would be willing to die to save the economy for their grandchildren

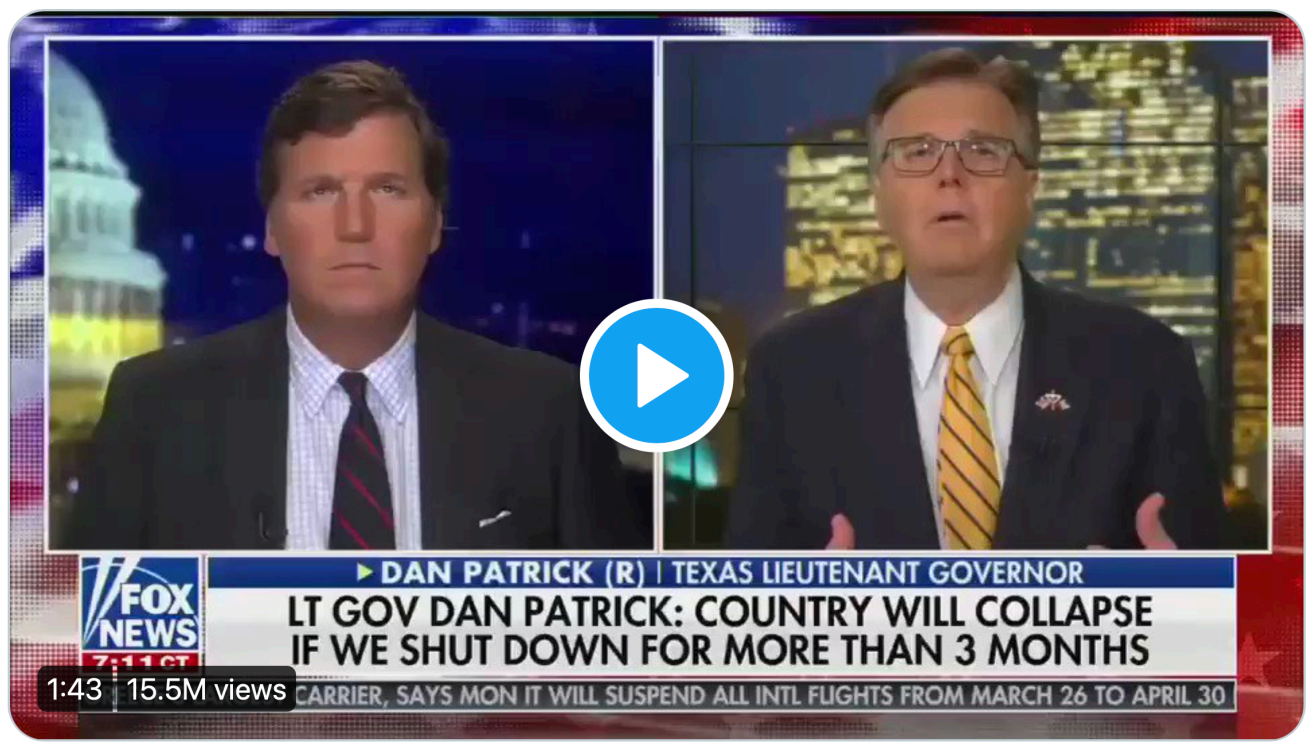

5:21 PM · Mar 23, $2020 \cdot$ SnapStream TV Search

13.1K Retweets $\quad$ 31K Quote Tweets $\quad$ 30.3K Likes 
Tellingly, although ostensibly about the human death toll, calls for responsibility focused on protecting infrastructures from being overwhelmed by patients or unemployment claims. The UK's National Health Service (NHS) slogan "Stay Home $\rightarrow$ Protect the NHS $\rightarrow$ Save Lives" encapsulated this idea perfectly (Figure 1). By caring for infrastructure-the "white spaces" within networks that potentially touch us all-you took care of yourself and others. Fears of becoming like Italy-becoming so overwhelmed that doctors had to choose whom to savedrove policies in countries with national health services (Mounk 2020). Almost all actions-even the lack of action in the face of a second wave-focused on hospital capacity. In other countries, such as the United States, the slogan would seem to have been "Work $\rightarrow$ Save businesses $\rightarrow$ Save your grandchildren's lives (and your pension, if you have one)" (Figure 2) (Klein 2020). Or, more positively, "Stay home/distant, flatten the curve, and save lives and the city." The pandemic revealed the enduring ties between public and private, rich and poor, that in good times were categorized as "absent ties" (Granovetter 1973, 1361).

The "cures" proposed, emergency powers granted, and sacrifices demanded reflected and revealed profoundly different national, regional, and local perceptions of which curve mattered-the number of "infecteds," the stock market, national employment figures, GDP, the mortality rate-and which ties bound most strongly-capital, public health, taxes, national deficits, public transportation. These differences stemmed, in part, from the two dominant and intersecting diagrams of the social: the network or the community.

\section{Networks: Modulating Segregation}

\section{Individual}

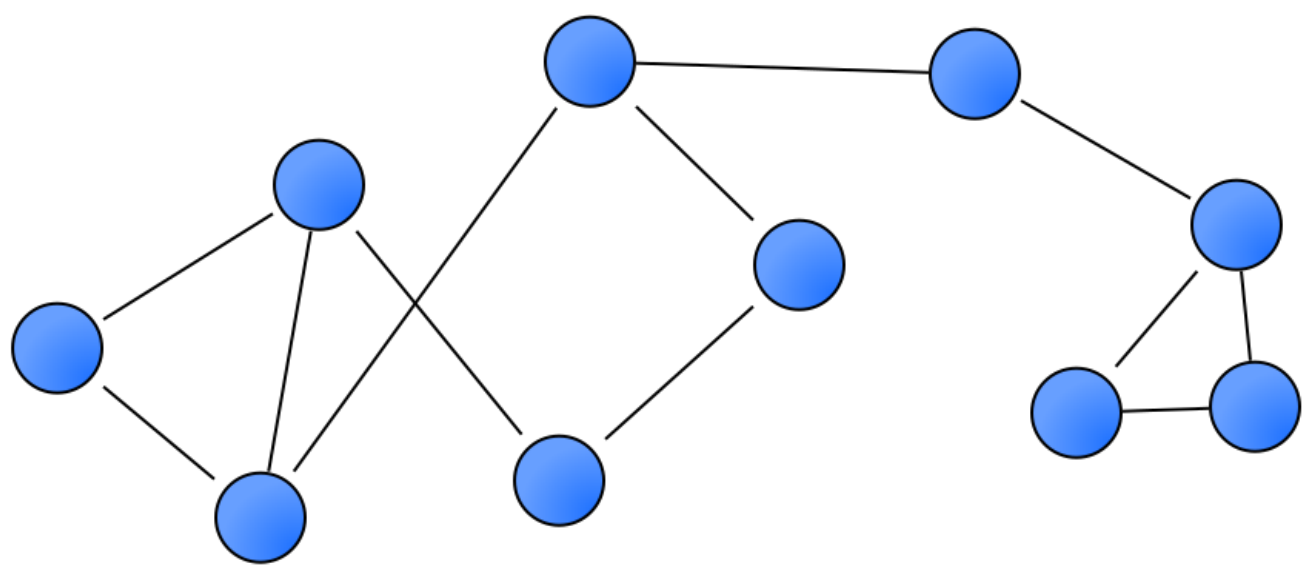

Figure 3: Network, from https://commons.wikimedia.org/wiki/File:Social-network.svg. 
If the nation is mainly viewed as a network (Figure 3), the goal is to produce "safe" neighborhoods: to create and/or augment clusters so that the "infected" are separated from the "recovereds" and "susceptibles." Surveillance to track and manage contagion and contacts becomes the key to amplifying "social distance." In this worldview, "community cases" become mysteries to be solved via stalking and recording "undocumented cases" and "silent spreaders." Tracking "patient zero" becomes a national pastime, as does blaming other countries for viral spread (Wald 2008; Chun 2016). Safety-resting as it does on inequality and dreams of emptying space-is precarious. Think of everything that must be erased for an edge to represent a friendship: institutions, such as schools and bars; social media prompts to say "happy birthday"; regular meetings and events; and interactions with nodding strangers. Networks are produced through subtraction, rather than simply addition. Again "white spaces" are filled with "absent" interactions habitually deemed not to matter.

Network clustering, central to social media networks and recommendation engines, presumes homophily_that "birds of a feather flock together." According to sociologists Miller McPherson, Lynn Smith-Lovin, and James Cook in their definitive review article on homophily, "the homophily principal structures network ties of every type, including marriage, friendship, work, advice, support, information transfer, exchange, co-membership, and other types of relationship" $(2001,415) .{ }^{1}$ As I have argued in detail elsewhere, homophily launders hate into love by treating racism as a "naturally" occurring preference within "human ecology" (Chun 2019). It transforms individuals into "neighbors" who naturally want to live with people "like them"; it presumes that consensus stems from similarity; it makes segregation the default. Not surprisingly, within studies of homophily, race and ethnicity are identified as creating the "biggest divide[s] in social networks," and US residential segregation is offered as the most prevalent example of homophily (Easley and Kleinberg 2010, 96).

Homophily's relationship to segregation is not accidental but fundamental. At the historical core of this concept lie studies of US residential segregation and white flight, reservations, internment camps, and other forms of "social engineering." Paul Lazarsfeld, then director of Columbia University's Bureau of Applied Social Research (BASR), and fellow Columbia University and BASR colleague Robert K. Merton coined the terms homophily and heterophily in their 1954 text "Friendship as Social Process: A Substantive and Methodological Analysis," which analyzed friendship patterns within two housing projects: "Craftown, a project of some seven hundred [white] families in New Jersey, and Hilltown, a bi-racial, low-rent project of about eight hundred families in western Pennsylvania" (Lazarsfeld and Merton 1954, 21). Crucially, they did not assume homophily to be a grounding principle; nor did they find homophily to be "naturally" occurring or causal. Rather, they asked, "What are the dynamic processes through which the similarity 
or opposition of values shape the formation, maintenance, and disruption of close friendships?" (28).

In the article, they focused on homophily within Hilltown, which was actually Addison Terrace, a housing project built through a "slum clearance" program in the Hill District of Pittsburgh, Pennsylvania. Finding racial and gender homophily to be almost absolute in Hilltown, they argued that this manifest "status homophily" (homophily based on social status such as "sex, race and age, social class organizational affiliation and standing in the local community") was driven by value homophily (the tendency of people to associate with others who share their values) (Lazarsfeld and Merton 1954, 21). To prove this, Lazarsfeld and Merton examined and modelled the racial attitudes of Hilltown's white residents. They focused on the answers to the following three questions from the BASR researchers' extensive interviews with one member of almost every household: "Q25. Do you think colored and white people should live together in housing projects?"; "Q26: On the whole, do you think that colored and white residents in the Village get along pretty well, or not so well?," and "Q37: Could you tell me who your closest friends are (regardless of whether or not they live in the Village)?" (26).

Based on the answers, they divided the white residents into three camps: liberals, who "believe that 'colored' and white people should live together in housing projects and who support this belief by saying that the two racial groups 'get along pretty well' in Hilltown"; illiberals, who "maintain that the races should be residentially segregated and who justify this view by claiming that, in Hilltown, where the two races do live in the same project, they fail to get along"; and ambivalents, who "believe that the races should not be allowed to live in the same project, even though it must be admitted that they have managed to get along in Hilltown" (Lazarsfeld and Merton 1954, 26). They then analyzed friendship patterns among white residents with white friends who resided in Hilltown and determined that liberals overselect other liberals by 43 percent; illiberals overselect other illiberals by 30 percent; liberals underselect illiberals as close friends by 53 percent; illiberals underselect liberals by 39 percent; and ambivalents do not overselect or underselect (27-28).

They presented these percentages without absolute numbers, numbers that they promised-in a footnote-would be forthcoming in a longer report, "Patterns of Social Life," written by BASR researchers Merton, Patricia J. West, and Marie Jahoda (Lazarsfeld and Merton 1954, 27). In another footnote they write, "It must be emphasized that such extreme concentration of personal ties within each racial group obtains only for the most intimate friendships. (It will be remembered that these data refer to the three closest friends of residents.) Short of these most intimate attachments, however, there have developed numerous personal relations across race lines in Hilltown, as will be seen in the complete report, 
Patterns of Social Life" (emphasis in original, 22). This forever forthcoming report-it was never published-actually discounts the statistical significance of the overselection of illiberals for other illiberals, since the total number of friendships was under fifteen. ${ }^{2}$

To prove that value homophily drove friendship patterns, they also speculated. The extensive interviews, on which Lazarsfeld and Merton based their argument, were only administered once. Because they were interested in friendship as dynamic social process, this static information would seem to pose an insurmountable challenge. ${ }^{3}$ To model the dynamic processes that cause over- and under-selection, Lazarsfeld and Merton thus left "demonstrated fact for acknowledged conjecture" because the authors could not afford "to become imprisoned in the framework of fact" (Lazarsfeld and Merton 1954, 29). Specifically, they hypothesized a reward-frustration model, in which "common values make social interaction a rewarding experience, and the gratifying experience promotes the formation of common values" (36). Racial liberals and illiberals made friends with those who hold the same opinion because they find their encounters to be "doubly rewarding": they get to "express deep-seated feelings" and they also receive satisfaction from having "these opinions endorsed by others" (30). In contrast, liberals and illiberals avoid each other because their values clash. Lazarsfeld and Merton viewed cross-value friendships as "unstable": they were presumed to have been formed prior to the revelation of racial attitudes.

To make this argument, they ignored the responses of Black residents. They removed their answers from their analysis of value homophily because there were "too few illiberal or ambivalent Negroes with friends in Hilltown" (Lazarsfeld and Merton 1954, 27; again, although there was also a very small number of illiberal white friends who chose illiberals, they retained this number). Thus, at the core of value homophily lies racial segregation-an implicit assumption that values do not cross racial borders, or if they do, that this crossing is less significant than consensus or conflict within a race-and racial exclusion. Yet at the same time, Black residents are central-their presence underlie the answers that "matter"even as their answers are muted. They are the gaps that enable connections to emerge.

The responses of the Black residents were not the only responses Lazarsfeld and Merton put aside. The responses of the white ambivalents-who comprised the largest category of white residents-were also discounted. This was because their value homophily model presumed the primacy of "comfort" and equilibrium. In Lazarsfeld and Merton's view, ambivalents were a temporary category-they would eventually have to become either illiberal or liberal in order to become consistent. 


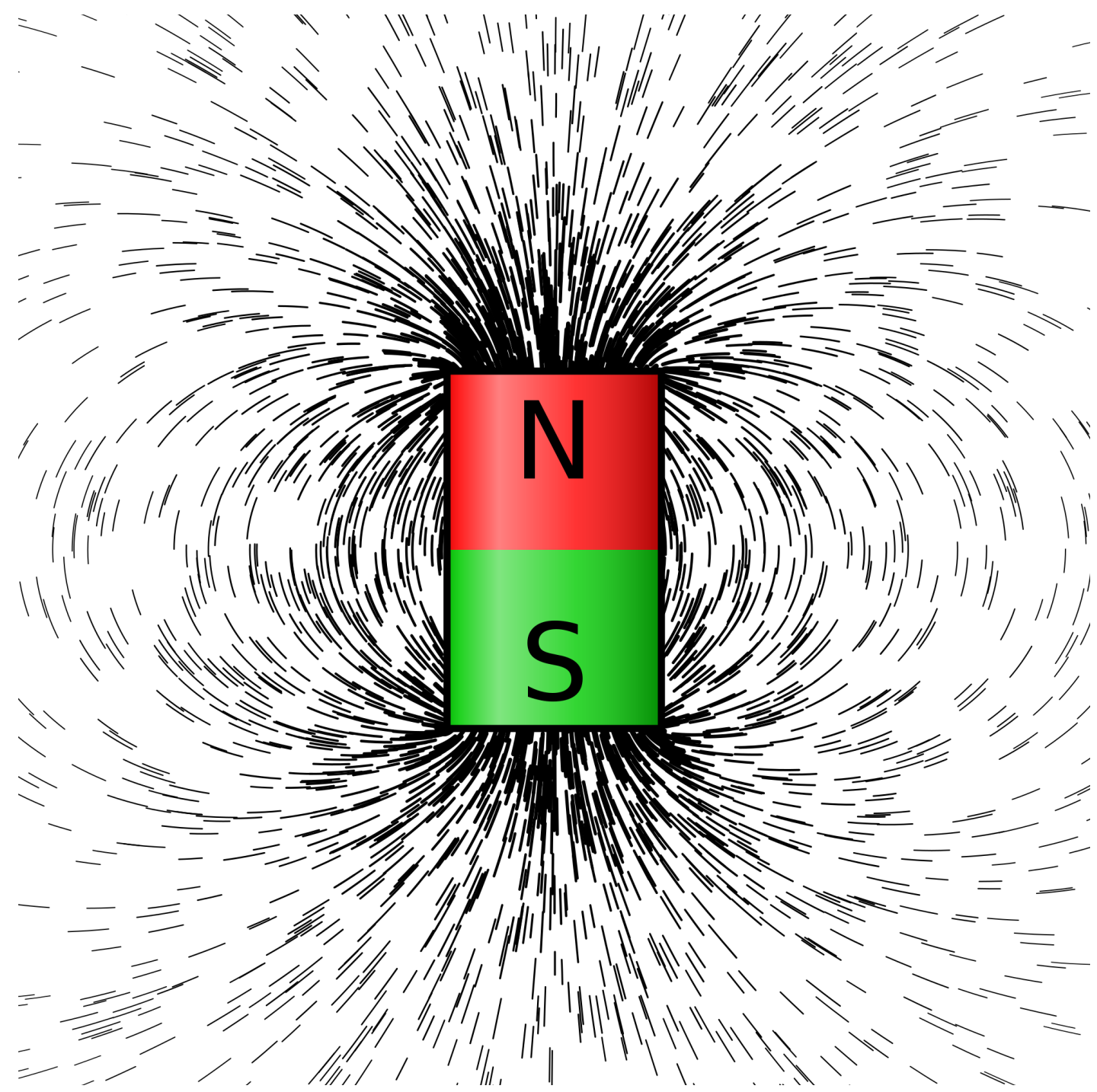

Figure 4: Representation of magnetically charged iron filings. Wikimedia Commons, https://commons.wikimedia.org/wiki/File:Ironfilings_cylindermagnet.svg

Networks emerge when masses are polarized and clarified. This polarization enables space to emerge and space-not nodes or edges-is the fundaments of networks. This process recalls the classic physics experiment in which a solid mass of inert iron pilings is magnetized and pulled into a clustered network. The similarly charged filings gathered at either pole repel each other, but they are stuck together by their overwhelming attraction to their opposite (Figure 4). Sustaining this magnetic charge in usually non-magnetic materials requires a previously charged magnet or a constant current.

This polarization creates the gaps, without which there can be no networks. Networks hollow clouds of uncertainty-that is, infra-structure and in/differenceto foreground clean connections across empty space. Networks dream of communication without community. What looks like or rhymes with community 
are individuals formed into agitated clusters of comforting rage that launder hate into love.

Crucially, when who is your neighbor becomes who is your friend, ethics becomes manipulation. Lazarsfeld and Merton's housing study foreshadows the "social engineering" central to contemporary social networks. They focused on close friendships because they were interested in social engineering, and new friendships were a proxy for its success: they revealed the extent to which a person's social life and habits had been rebuilt. In their funding application to the Lavanberg Foundation for their housing study, Merton referred not only to the pressing problems of US housing but also the need to understand and implement "good" social engineering. ${ }^{4}$ In "Patterns of Social Life," Merton, West, and Jahoda described public housing projects as "new social worlds," in which habits were disrupted and formed; they were closed communities, ideal for study and experimentation. They compared the "world laboratory of the sociologist" to that of "the more secluded laboratories of the physicist and chemist" (Merton, West, and Jahoda 1951, Chapter 1, 30). Public housing projects were ideal spaces for experimentation and evaluation because they were fundamentally disruptive. ${ }^{5}$

As the docu-drama The Social Dilemma and many others have pointed out, this laboratory/project now engulfs us all (Orlowski 2020). Acclaimed network scientist and author Albert-László Barabási has claimed that network science, combined with "increasingly penetrating digital technologies," places us in "an immense research laboratory that, in size, complexity, and detail, surpasses everything that science has encountered before" and that reveals "the rhythms of life as evidence of a deeper order in human behavior, one that can be explored, predicted, and no doubt exploited" $(2010,11)$. Data scientist and journalist Seth Stephens-Davidowitz proclaimed in 2017 that big data "allows us to undertake rapid, controlled experiments" $(2017,54)$. These experiments have moved from simple A/B testing to contextual bandits to reinforcement learning: all techniques to "optimize" content based on users' prior interactions (see Tang et al. 2013).

Thus, the logic of networks spreads the name "neighbor" everywhere, even asand in order to-empty it conceptually. Machine learning is filled with "neighborhood" methods used for pattern recognition, such as K nearest neighbor and $\mathrm{K}$ means testing. The $\mathrm{K}$ nearest neighbor algorithm draws boundaries between data points based on proximity; it presumes that those data points closest to each other geographically/topographically are of the same class. $\mathrm{K}$ means testing similarly uses proximity to intuit the existence of clusters, or neighborhoods. These methods, and networks more generally, presume homophily. By doing so, they naturalize segregation, transforming hatred into love. In a homophilic world, how do you show you love the same? By fleeing when others show up. This transformation of neighbors into friends makes racism 
latent, under the bar, resonating everywhere, especially within the "spaces" that are not empty but teeming with relations that haunt them.

\section{Community Transmission}

If this is the view from the perspective of networks, the other approach towards pandemics is that of community. If the nation is mainly viewed as a community, the onset of non-trackable cases demands treating everyone as "infected," to suppress the disease. Viruses, such as SARS Cov-1, have been eradicated without vaccines; New Zealand and Australia successfully suppressed the first wave of SARS Cov-2 through programs based on mass quarantines. The Vancouver Parks motto "the space between us will hold us together" encapsulates this vision; rather than treating the population as a series of nodes and edges, it attends to the spaces that enable community to emerge (Crawford 2020). Community presumes community transmission-community is transmission and space (Nancy $1991,19)$. Once a virus is endemic to a community, neatly drawn graphs become impossible-almost everyone is in contact-and the goal becomes widespread habitual changes to save others and public infrastructures: physical distancing, wearing facemasks, washing hands, avoiding mass gatherings, cleaning public spaces. Even as the disease and these changes affect "vulnerable" populations differently, there are no exceptions to the call for-if not the act of-sacrifice. Friends and mobility become dangerous and addressing the needs of "at risk" populations becomes key.

At its best, the logic of community follows the call made by the Combahee River Collective in 1977 to treat everyone as "levelly human," by engaging—rather than ignoring-identity politics and individual experience. ${ }^{6}$ In British Columbia and elsewhere, houseless populations during the first wave were finally moved into safer shelters, such as hotel rooms and empty apartment buildings, after individual consultations. Shamefully, Vancouver's long-standing housing and drug crises were addressed not because of the dangerous living conditions of the houseless or the crisis of missing and murdered Indigenous women or the overdose crisis public health emergency declared in 2016, but because of the need to contain COVID-19 (the death toll in British Columbia due to illicit drug toxicity dwarfs the number of those who died from COVID-19).

This sheltering and claiming of the commons, however, can also destroy. The construction of spiked fencing to prevent tents from re-emerging in Vancouver's Oppenheimer Park raises calls for constant vigilance and makes it clear that this commons-based "clearing" is not outside racism or forced segregation. Oppenheimer Park, after all, is part of unceded lands of the Squamish, Musqueam, and Tsleil-Waututh First Nations and the tragic setting of another clearance: Japanese Canadians were removed from this area into Interior internment camps during World War II. Communities, as many have argued, are not idyllic spaces, especially when they are defined in terms of shared or 
homogenous values and identities. ${ }^{7}$ Racism, at a fundamental level, targets communities-and communities and identities form in its wake. As Asian American studies scholars Patricia Wong Hall and Victor M. Hwang, summarizing the work of attorney Michelle Yoshida, explain, hate crimes transfer their effects "from the targeted victim to others who also suffer the consequences of illegal acts driven by bigotry, intolerance, and ignorance" (Hall 2001, 2). Asian American, as an identity, formed in response to such "group" attacks. As theatre and performance studies and Asian American studies scholar Karen Shimakawa, drawing from the work of Asian American studies researchers Yen Le Espiritu, Glenn Omatsu, William Wei, and others, has argued, the term Asian American as a "panethnic self-identified political social coalition/identity" is a response to panethnic anti-Asian racism $(2002,2)$.

Asian-American not only responds to violence that does not distinguish between immigrants from Southeast, East, South Asia, the Pacific Islands and their U.S. descendants; it also establishes relations to other racialized groups. The Vancouver "clearing" embodies what critical ethnics studies researcher Quynh Nhu Le, based on her extended study on Asian and Indigenous crossrepresentations-from tropes of the Asian as "perpetual foreigner" to that of Indigenous persons as "vanishing Indians"-has called "settler racial tense" (2019, 5). ${ }^{8}$ Indigenous studies scholar Jodi Byrd, analyzing US Commissioner of Indian Affairs John Collier's impact on the management and formation of the Poston Internment Camp during World War II, has argued that Poston reveals how "the transit of Indianness" transcribes empire internally and externally $(2011,188)$. Poston was named after Charles Debrille Poston, the first superintendent for Indian Affairs in Arizona, and "housed" within the Colorado River Indian Reservation near Parker, Arizona (Burton et al. 2002, 215). Most provocatively, Byrd states that blanket celebrations of "the common" can "make a commons out of internment camps" (2011, 205). This "making common," as the rest of this article outlines, extends beyond land to networks and their "communal" formations-especially when they "contain" ethnic identities within them.

Poston was the largest internment camp in the US, and was the only camp managed by both the Office of Indian Affairs (OIA; later the Bureau of Indian Affairs [BIA]) and the War Relocation Authority (WRA) (Okimoto 2001, 6). Initially, the OIA and WRA viewed Poston as mutually beneficial: it was to provide the WRA with a large swathe of public land for its camp, as well as internee labor to irrigate and settle the land and to put in place improvements that the OIA had promised but failed to enact since 1865 when it first chose this land as a reservation for the Mohave and the Chemehuevi Nations-against these nations' warnings about the poor quality of the soil (Caylor 2000). The internees were to develop permanent resources-"irrigation canals, roads, land leveling, domestic water supply, powerlines and some...buildings"-that would later be used by Hopi "colonists," who were to be integrated into what was then called the Colorado 
River Indian Tribes (Okimoto 2001, 12). This partnership, however, fell apart, partly due to the conflicting interests and attitudes of the two organizations. In December 1943, the WRA took full control and in 1944 replaced Poston Director Wade Head, formerly a superintendent of the Papgo Indian Reservation in Southern Arizona and a director of an agricultural school in the Philippines. (Muller 2005, 135).

In Poston, the OIA sought to "democratize the enemy" (Hayashi 2004), just as it had aimed to create reservations as "exceptional states" of sovereignty-models of true democracies, "founded in neighborhoods and reaching over the world" (John Collier, quoted in Byrd 2011, 193). As Byrd stresses, Collier viewed reservations as exceptional and romantic spaces of American multicultural democracy, and Collier fought for "the federal recognition and nation-to-nation status of indigenous nations colonized by the United States" because he believed "American Indian democracies to be deeper and thicker democracies than those of the West" (Byrd 2011, 194). As seductive and affirming as Collier's sovereign vision might be, Byrd stresses that it lies at the "intersection of colonial and racist agendas that collude to oppress on the one hand and offer the seductive recognitions that maintain state hegemony on the other" (194). As psychiatrist Alexander Leighton who directed one of the projects to study the internment camp put it, Poston was built on principles in accord with the "general administrative experience of the Indian Service" most bluntly because it sought to promote self-governance and self-sufficiency while still interning and oppressing evacuees. It "encouraged" Japanese Americans to become independent and gain self-respect through work to overcome the "great shock" of internment and to prove their "future usefulness as members of the American nation...[and] to make a record that the rest of the country could appreciate." Further, by developing the land around Poston and through self-government, Poston and the other internment camps were to show that "the United States could carry out a program of evacuation and relocation in a democratic manner that would provide the greatest possible contrast to population shifts in Axis countries" (Leighton 1945, 49).

Further, the OIA viewed Poston and other internment camps-like its reservations-as prime sites for anthropological and sociological investigation. This research was not incidental but central to these camps for they were to reveal the general problems related to administering and governing occupied areas (Leighton 1945, vii-viii). Indeed, assistant Secretary John McCloy objected to the early release of Japanese Americans from the camps because doing so would entail "missing a very big opportunity...to study the Japanese...[and to]...find out what they are thinking about and [how] we might very well influence their thinking in the right directions before they are again distributed into communities" (quoted in Hayashi 2004, 138). Collier hired Leighton, who had previously studied Navaho and Inuit communities, to lead the fieldwork via the 
Bureau of Sociological Research (BSR), which was established three years before and one vowel away from the Lazarsfeld and Merton's BASR. Reservations, internment camps, and housing projects were all sites of sociological analysis and experimentation. ${ }^{9}$ The level of hostility directed toward the administration, however, made internment camps particularly challenging and thus necessitated the use of "participant observers" (Hirabayshi 1995). As a sign of its importance, Poston was the subject of three different research projects: the BSR (June 1942September 1943); the more "secretive" Japanese American Evacuation and Resettlement Study (early 1942-summer of 1945), run by researchers at UC Berkeley; and the WRA's Community Analysis section.

These sociologists were on hand to document widespread distrust, which led to a general strike in Poston 1. Despite the early presence of and leadership by "volunteers," who sought to ensure a "harmonious relationship" with the administration, (Hayashi 2004, 98), Poston and many camps did not become the model communities the OIA and WRA envisioned. For one, they hardly provided the needed quotient of "security and....acceptance as fellow Americans and friendly aliens" needed for Japanese Americans internees to become prototypical "model minorities" (Leighton 1945, 50). ${ }^{10}$ The accommodations, which were supposed to showcase the generosity and spirit of American democracy, were poorly built-without double floors and made with green timber that shrunk so that there was little to no protection against the dust, heat, and cold (Hayashi 2004, 91; Burton et al. 2002, 216). It was so bad that General DeWitt and his staff "personally ordered a number of barracks redone...[since] he feared that inadequate facilities would lead to disaffection among loyal Japanese Americans" (Hayashi 2004, 91). The evacuees called Poston 1, 2, and 3 "Roasten, Toasten, and Dustin" (Burton et al. 2002, 215). Further, the wages offered to the internees for back-breaking work were not only substandard, they were also often not paid or delayed due to so-called clerical errors (half the staff at Poston thought it should be run as a concentration camp) (Leighton 1945, 85). Further, camp directives were constantly changing, and there was a general fear of and anger towards FBI "informants" amongst the internees.

Leighton's Governing of Man, the published results of the BSR study, focused on unpacking the significance, evolution, and aftermath of the general strike not only to Poston but more generally to "the rights of citizens, the treatment of minority groups in the heart of a nation and the capacity of a democracy for efficient, consistent government and just international relations" $(1945,4)$. Describing the scene outside the jail as reminiscent of "a holiday and a mass picnic.... revival meeting...[or] a lynching party," Leighton stressed the centrality of the strike to understanding the "recurrently human" breakdown of organizations (3). In a remarkable passage, Leighton argued, 
The most important question that hung over the Center, seething in the growing dusk like bees about to swarm, was not what would the crowd do, was not what the Administration or the Army would do, nor what the Government, Congress or the American public would think. It was not a matter of who was right or who was wrong. It was not a question asked by anybody present and concerned, but it might have been asked by the detached visitor. It was the question of what in all this is recurrently human. What are the laws of individual behavior, what are the perennial social forces at work here? Under the confusion, under the excited passions, amidst all the milling and crosspulling, what general characteristics of human nature are in action, a knowledge of which would prevent such sudden diseases of society as this? The breakdown of man's organizations of himself and his fellows are not events isolated in evacuation camps. They cover as much of the earth as is covered by the human race, and questions that run deeply into the fate of mankind in a shrinking world are involved. (4)

Poston revealed how disorganization and the "breakdown of man's organizations" could lead to revolt-and how this revolt could be effectively managed to enact even more concessions from internees. Leighton's principles and recommendations focused on how to deal with individuals, systems of belief, and social organizations under stress, and how best to introduce changes into communities under these conditions. His goal, like Merton's, was social engineering, albeit one designed to control via respecting "national or cultural differences" within occupied territories.

Crucially, Leighton stressed the importance of sentiment. Methodologically, he "conceived the understanding of the community as being dependent upon knowledge of its patterns of sentiment and its social organization" (Leighton 1945, 383). Sentiment colored every decision and action; thus, the BSR's main questions were:

1. What are the predominant sentiments in the community?

2. How well are these adjusted to the biological needs of the people and do they facilitate or interfere with the attainment of these needs?

3. How do the sentiments contribute to the satisfactory living of the people in relationship to each other and to the administration?

4. Which sentiments are most modifiable and which are most resistant? In what directions can modification be achieved most easily?

5. What are the principal groups of people in the community and how are they related to each other and to the total social organization?

6. What sentiments are characteristic of what groups? 
7. On the basis of a knowledge of the social organization and the sentiments found in its different parts, what kinds of action may be expected from the community as a whole or from its principal parts?

8. To what extent is the administrative program realistically geared to what the community can do on the basis of its predominant sentiments and social organization?

9. To what extent are the methods used by the administration to achieve its program realistically geared to what the community can do on the basis of its predominant sentiments and its social organization? (Leighton 1945, 388)

Sentiment, analogous to "conditional reflexes...studied extensively in lower animals" was key to successful social engineering under conditions of captivity and stress (384). At the heart of sentiment analysis-so key to current forms of social media analysis, manipulation, and research-lie unruly women workers and Japanese American internees. ${ }^{11}$

\section{Holding onto In/Difference}

To reiterate, for there to be networks, there must be gaps, but these gaps are never empty. These gaps-teeming with abjected "communities"—create clean nodes and edges. This abjection is central to the formation of "ethnicness" more generally and Asian Americanness in particular. Shimakawa, rereading Frank Chin's character Tam Lum's description of the Chinaman in The Chinacoop Chinaman as "made, not born... out of junk-imports, lies, railroad scrap iron, dirty jokes, cigar smoke, Cosquilla Indian blood, wino spit, and lots of milk of amnesia" (Chin as quoted by Shimakawa 2002, 1) has argued that Asian Americanness emerges through "an attempt to circumscribe and radically differentiate something that, although deemed repulsively other is, paradoxically, at some fundamental level, an undifferentiable part of the whole" (2). Drawing from psychoanalytic researcher Julia Kristeva's definition of the abject as a "frontier," Shimakawa further argues, "read as abject, Asian Americanness thus occupies a role both necessary to and mutually constitutive of national subject formationbut it does not result in the formation of an Asian American subject or even an Asian American object" (3). This "nothingness" that is Asian Americanness and racialized identities is nonetheless centrally there-as gaps, spaces, and frontiers. Networks are fundamentally melancholic: they incorporate within themselves others so that what seems absent radiates everywhere. ${ }^{12}$ They are formed by the introjection of Black residents, Japanese internees, and Indigenous residents on reservations, among so many others.

Yes, but if this is so, what can we do? 
The "correlation" between these groups also offers ways to move and live against this logic. The Colorado River Indian Reservation Tribal Council opposed the use of their land for a relocation center because they did not want to participate in inflicting the same type of injustice they had suffered (Burton et al. 2002, 215). Intriguingly, the white sociologists read this resistance as "misplaced" anger.

Edward Spicer, the first "community analyst of Poston" and assistant to Leighton, "observed" that "the attitude of the Indians on the local reservation at first was extremely antagonistic toward the Japanese. It took the form, however, of antagonism toward the Caucasian for permitting the Japanese to come on the reservation at least as much toward the Japanese themselves" (quoted in Hayashi 2004, 89). What Spicer frames as "misplaced" antagonism was actually on point. How might these observations be used to reveal different worlds that existed and still exist-however seemingly "out of place"? That is, how might we follow African American studies researcher and queer theorist Kara Keeling's call for us to "listen, with others, for the poetry, the refrains, and the noise a world is making" (Keeling 2019, ix)?

For one, by revisiting the BASR housing study report and its archival traces, we would realize that racial homophily was not absolutely within the projects. Embedded within this report and the archive are threads that pull at the narrative of complete racial and gendered homophily. Gender homophily was only absolute if family members and couples were invalidated as "close friends." Further, as Lazarsfeld and Merton acknowledged, their choice of "three closest friends" regardless of where they lived to measure homophily went against the usual ways for accounting for friendship. (Intriguingly, residents bristled at being asked who their three closest friends were-it was the part of the survey about which they had the most questions (PJS and JAM 1947, 2). As I explain in more detail in Discriminating Data (2021) the overwhelming majority of all residents at Hilltown $(87 \%)$ believed that the races got along well in the project, and the majority $(60 \%)$ thought that public housing should be integrated. Only a very small minority-8 percent-believed that Black and white residents were getting along worse than when they first arrived and only 17 percent believed that there was more conflict than expected. Eighty-eight percent said that they had a neighbor of the other race before they had moved in. Further, the majority of residents, from both races, had made acquaintances of the other race in Hilltown, and the majority of Black residents and a significant portion of the white residents, $86 / 354$ or 25 percent, had friends of the other race (for more on this and other answers to the questions, see Chun 2021, 116-17).

The predominant attitude was arguably that of engaged in/difference. The Black residents-whose answers were recorded but not accounted for-supported integrated housing because they believed that "everybody's equal" and should have the same opportunity to live well. Mid-century public housing-which afforded all residents luxuries such as hot water, electric fridges and stoves, access 
to laundry facilities-seemed to acknowledge and remedy the fact that Black residents in the US were forced to pay higher rents than their white counterparts for substandard housing. As one woman put it, "I would welcome any whites here who wanted to come, but I'm not going to go out of my way to get them to come here" (JGB 1946, 5, 4). Indifference, ambivalence, and uncertainty are not simply "unstable" categories, but rather modes and means of residing together in and through spaces of conflict. Neighbors are not innocuous-the term neighbor literally recalls "boors." They are nosy and noisy. They provoke hostility, resentment, and ambivalence. They intrude, even-and especially-when they are inert. They offer, however, a way to reside in/difference and to engage relations that go beyond homophily: not just heterophily (heterosexuality, electromagnetism, and other opposites that attract), but also ambivalence and neutrality.

Neighbors-who are neither friends nor enemies-are the space that enable the public and private to emerge (Reinhard 2005). According to literary critic Kenneth Reinhard, if as political theorist Carl Schmitt has argued, the political hinges on distinguishing between the friend and the enemy, the neighbor "supplements"and thus makes inadequate-the political theology of the sovereign (Schmitt 2007, 26; Reinhard 2005, 74). The logic of the neighbor, Reinhard insists, is not that of totality, but rather infinity: in the (feminine) set of the neighbor, there is no sovereign exception, but instead an infinite process of knotting-everyone is equally non-sovereign $(2005,62)$. To put it in philosopher Édouard Glissant's (1997) terms, the neighbor is opaque and obscure; their non-transparency, however, does not hinder but rather enables relation. Refusing our grasp/embrace, they subtract unity from the open totality that is Relation (Glissant 1997, 91). These spaces make us all topological neighbors-they touch everything.

The questions that remain as we reside-if we are to still reside-are these: How can this uncertainty and ambivalence, which touches us all, ground our future? How might the space between us-the empty space of power-create solid(arity) so that the space between us can hold open the future?

\section{Acknowledgments}

This research was supported by the Canada 150 Research Chairs Program and the Digital Democracies Institute at Simon Fraser University. The author would like to thank Hannah Holtzclaw and Amy Harris for their assistance. An earlier version of this article was published in Critical Inquiry.

\section{Notes}

${ }^{1}$ McPherson et al. list the following as causes of homophily: geography ("the most basic source of homophily is space"); family ties; organizational foci, occupational, 
family, and informal roles; cognitive processes; and selective tie dissolutions (2001, 429-35).

${ }^{2}$ I'm referring specifically here to the note on "Chart 1: Racial Values of Close Friends Among White Residents of Hilltown" (Merton, West, and Jahoda 1977, Chapter 8,9 ). This chart was not included in the version of Chapter 8 in the Merton Archive. It is located in Columbia University, Bureau of Applied Social Research, 1938-1977, MS0166, Box 09, Rare Book and Manuscript Library, Columbia University Library.

${ }^{3}$ Lazarsfeld and Merton write, "the dynamic role of similarities and differences of these values in forming, maintaining, or disrupting friendships...requires notice in its own right" (1954, 25).

${ }^{4}$ In his funding request to the Lavanburg Foundation, a "neutral" entity responsible for creating low-income nonprofit housing in Manhattan, Merton offered to write a report that was "(1) technically competent; (2) fact-finding and not moralizing; (3) pertinent, i.e., centered on problems which confront housing personnel; and (4) sufficiently detailed to serve as a guide to social engineering" $(1944,2)$.

${ }^{5}$ Merton, West, and Jahoda begin their report by acknowledging that a change in environment calls into question the normal relationship between past, present, and future. Moving into a new house is particularly disruptive for those who do because it impacts the "the routine habits of everyday life: the new rooms differ from the old in shape and size, furniture must be shifted to unfamiliar positions, the journey to work is different as is the way to one's friends and group activities.... The neighbors might turn out to be crude or snobbish or just right, which probably means people like oneself. At such times, reluctance and hopeful anticipation mingle in varied degrees, according to personality and social circumstance" (1951, Chapter 1, 1).

${ }^{6}$ The Combahee River Collective, a collective of Black socialist feminists, were one of the earliest groups to formulate what would become identity politics and intersectionality $(2017,19)$. They argued for solidarity, rather than separatism, with progressive Black men, noting, "our situation as Black people necessitates that we have solidarity around the fact of race...We struggle together with Black men against racism, while also struggle with Black men about sexism" (19). Crucially, they called for a level humanity, from their base in identity politics and their work for self-liberation: "we believe that the most profound and potentially most radical politics come directly out of our own identity, as opposed to working to end somebody's else's oppression... We reject pedestals, queenhood, and walking ten paces behind. To be recognized as human, levelly human, is enough" (19). 
${ }^{7}$ For more on the limits and possibilities of community, see Nancy 1991.

${ }^{8}$ Le (2019) develops this notion through her reading of the differences and similarities between the Canadian government apologies to Japanese Canadians for internment and Indigenous Peoples for past injustices, including the horrific residential school system.

${ }^{9}$ Merton, West, and Jahoda refer directly reference Poston and Alexander Leighton's The Governing of Men in their report: both in terms of their need not to use participant observation since the housing projects were not placed in a hightension community or a community fearing authority (1951, Appendix, 78). They also note that social research has been "applied much more frequently to the lower income strata than to the wealthy. This is only partly the aftermath of an early period in which social research was closely related to social reform and the problems of the poor. With the growing emphasis of sociology on the functioning of normal society independent of symptom of social pathology, the demand for studying all sectors of society has become urgent. However, it appears that without participant observation the study of a millionaires' club in New York or the directorate of a major industrial concern, for instance, meets more formidable obstacles than that of, say, the Navaho Indians" (78-79).

${ }^{10}$ This program also depended on discerning "loyal" Japanese Americans from the bad, just as the US military historically discerned the "'good injuns' and 'bad' ones" (Hayashi 2004, 79).

${ }^{11}$ Leighton cites the work of Fritz Jules Roethlisberger, in particular Management and Morale (1941), and Roethlisberger and William J. Dickson's Management and the Worker (1939). Sentiment analysis is now a key technique used in natural language processing to "understand" opinions. See, for example, Li et al. 2019.

${ }^{12}$ In making this observation, I am drawing from and expanding upon Anne Cheng's provocative argument that "racial melancholia is both the technology and nightmare of the American Dream," for both white culture and racial others. In making this argument, Cheng draws from Sigmund Freud's famous distinction between mourning and melancholia. In the normal process of mourning, a subject gradually accepts loss by relinquishing the lost object and eventually substituting another for it. In contrast, melancholics cannot get over their loss and thus impoverish themselves, rather than the world. As Cheng notes, however, this impoverishment is also a form of consumption, in which the libido that was once attached to the lost object is "withdrawn into the ego...to establish an identification of the ego with the abandoned object... The ego wishes to incorporate this object into itself, and the method by which it does so... is by devouring it" (Cheng 2001, 7-8). 


\section{References}

Ambrose, Jillian. 2020. "Oil Prices Dip below Zero as Producers Forced to Pay to Dispose of Excess." The Guardian, April 20, 2020.

https://www.theguardian.com/world/2020/apr/20/oil-prices-sink-to-20-year-low-asun-sounds-alarm-on-to-covid-19-relief-fund.

Amoore, Louise. 2013. The Politics of Possibility: Risk and Security beyond Probability. Durham, NC: Duke University Press.

Associated Press. 2020. "China's Economy in Worst Downturn since '70s amid Coronavirus Battle." CBC News, April 17, 2020.

https://www.cbc.ca/news/business/china-economy-coronavirus-1.5535584.

Barabási, Albert-László. 2010. Bursts: The Hidden Pattern behind Everything We Do. New York: Dutton.

Burton, Jeffery, Mary Farrell, Florence Lord, and Richard Lord. 2002. Confinement and Identity: An Overview of World War II Japanese Relocation Sites. Seattle: University of Washington Press.

Byrd, Jodi. 2011. The Transit of Empire: Indigenous Critiques of Colonialism.

Minneapolis: University of Minnesota Press.

Caylor, Ann. 2000. "'A Promise Long Deferred': Federal Reclamation on the Colorado River Indian Reservation." Pacific Historical Review 69 (2): 193-215.

https://doi.org/10.2307/3641438.

CDC. 2020. "Communities, Schools, Workplaces, \& Events." Centers for Disease Control and Prevention, April 30, 2020. https://www.cdc.gov/coronavirus/2019ncov/community/health-equity/race-ethnicity.html.

Chappell, Bill. 2020. "WHO Says COVID-19 Immunity Is an Unknown; Disease '10 Times Deadlier' than 2009 Flu." NPR, April 13, 2020. https://www.npr.org/sections/coronavirus-live-updates/2020/04/13/833534116/whosays-covid-19-immunity-is-an-unknown-disease-10-times-deadlier-than-2009-flu.

Cheng, Anne Anlin. 2001. The Melancholia of Race: Psychoanalysis, Assimilation, and Hidden Grief. Oxford. UK: Oxford University Press

Chun, Wendy Hui Kyong. 2016. Updating to Remain the Same. Cambridge, MA: MIT University Press.

- 2019. "Queerying Homophily," in Pattern Discrimination, edited by Clemens Apprich. Minneapolis, MN: Minnesota University Press, 59-97.

- 2021. Discriminating Data: Correlation, Neighborhoods, the New Politics of Recognition. Cambridge, MA: MIT Press.

Combahee River Collective. 2017. "The Combahee River Collective Statement" in How We Get Free edited by Keeanga-Yamahtta, 15-27. Chicago: Haymarket Books. 
Crawford, Tiffany. 2020. "COVID-19: Vancouver Park Board Champions to Patrol Beaches, Parks." Vancouver Sun, April 4, 2020. https://vancouversun.com/news/localnews/covid-19-vancouver-park-board-champions-to-patrol-beaches-parks/.

De Leon, Adrian. 2021. "The Long History of US Racism against Asian Americans, From 'Yellow Peril' to 'Model Minority' to the 'Chinese Virus.'" The Conversation, April 8, 2021. https://theconversation.com/the-long-history-of-us-racism-against-asianamericans-from-yellow-peril-to-model-minority-to-the-chinese-virus-135793.

Easley, David, and Jon Kleinberg. 2010. Networks, Crowds, and Markets: Reasoning about a Highly Connected World. New York: Cambridge University Press.

Elliott, Josh K. 2020. "'A Symbol of Hatred': Shopper Spotted in KKK Hood under Coronavirus Mask Rule in California." Global News, May 4, 2020. https://globalnews.ca/news/6g02152/coronavirus-ku-klux-klan-mask.

Glissant, Édouard. 1997. Poetics of Relation. Translated by Betsy Wing. Ann Arbor: University of Michigan Press.

Granovetter, Mark. 1973. "The Strength of Weak Ties." American Journal of Sociology 78 (6): 136o-8o. https://doi.org/10.1086/225469.

Hall, Patricia Wong. 2001. "Introduction." In Anti-Asian Violence in North American: Asian American and Asian Canadian Reflections on Hate, Healing and Resistance, edited by Patricia Wong Hall and Victor M. Hwang, 1-26. Walnut Creek, CA: AltaMira Press.

Hayashi, Brian Masaru. 2004. Democratizing the Enemy: The Japanese American Internment. Princeton, NJ: Princeton University Press.

Hirabayshi, Lane Ryo. 1995. "Introduction: Why Read Nishimoto?" In Inside an American Concentration Camp, by Richard S. Nishimoto, edited by Lane Ryo Hirabayshi, xxxvi-ii. Tucson: University of Arizona Press.

Ho, Jennifer. 2021 "Anti-Asian Racism, Black Lives Matter and COVID-19." Japan Forum 33 (1): 148-59. https://doi.org/10.1080/09555803.2020.1821749.

Jeung, Russell, Aggie Yellow Horse, Tara Popovic, and Richard Lim. 2021. Stop AAPI Hate National Report, 3/19/20-2/28/2021. https://stopaapihate.org/wpcontent/uploads/2021/05/Stop-AAPI-Hate-Report-National-210316.pdf.

JGB. 1946. "Tenant: Helen Brown," December 19, 1946. Columbia University, Bureau of Applied Social Research Papers, MSo166, Box 08, Rare Book and Manuscript Library, Columbia University Library.

Keeling, Kara. 2019. Queer Times, Black Futures. New York: NYU Press.

Keenan, Thomas. 1997. Fables of Responsibility: Aberrations and Predicaments in Ethics and Politics. Stanford, CA: Stanford University Press.

Klein, Ezra. 2020. "The Debate over Ending Social Distancing to Save the Economy, Explained." Vox, March 27, 2020. https://www.vox.com/coronavirus- 
covid19/2020/3/27/21193879/coronavirus-covid-19-social-distancing-economyrecession-depression.

Lazarsfeld, Paul, and Robert K. Merton. 1954. "Friendship as Social Process: A Substantive and Methodological Analysis." In Freedom and Control in Modern Society, edited by Morroe Berger, Theodore Abel, and Charles Page, 18-66. New York: Van Nostrand.

Le, Quynh Nhu. 2019. Unsettled Solidarities: Asian and Indigenous CrossRepresentations in the Americas. Philadelphia, PA: Temple University Press.

Leighton, Alexander H. 1946. The Governing of Men: General Principles and Recommendations Based on Experience at a Japanese Relocation Camp. Princeton, NJ: Princeton University Press.

Li, Zuhe, Yangyu Fan, Bin Jiang, Tao Lei, and Weihua Liu. 2019. "A Survey on Sentiment Analysis and Opinion Mining for Social Multimedia." Multimedia Tools and Applications 78 (6): 6939-67. https://doi.org/10.1007/s11042-018-6445-z.

Manojlovic, Drazen. 2021. Report to the Vancouver Police Board: Year-End 2020 Yearto-Date Key Performance Indicators Report. Board Report \# 2102P01. February 3, 2021. https://vancouverpoliceboard.ca/police/policeboard/agenda/2021/0218/5-12102P01-Year-end-2020-KPI-Report.pdf.

Martineau, Paris. 2020. "What's a 'Shelter in Place' Order, and Who's Affected?" Wired, March 20, 2020. https://www.wired.com/story/whats-shelter-place-orderwhos-affected/.

McPherson, Miller, Lynn Smith-Lovin, and James M. Cook. 2001. "Birds of a Feather: Homophily in Social Networks." Annual Review of Sociology, 27, 415-44. https://doi.org/10.1146/annurev.soc.27.1.415.

Merton, Robert K. 1944. "Memorandum: A Proposed Research in Housing Committees." Columbia University Bureau of Applied Social Research, 1938-1977, MS0166, Box 9, Folder B-0230, Rare Book and Manuscript Library, Columbia University Library.

Merton, Robert K., Patricia West, and Marie Jahoda. 1951. "Patterns of Social Life: Explorations in the Sociology of Housing." Columbia University, Bureau of Applied Social Research, 1938-1977, MS0166, Box 09, Rare Book and Manuscript Library, Columbia University Library.

Mounk, Yascha. 2020. "The Extraordinary Decisions Facing Italian Doctors." The Atlantic, March 11, 2020. https://www.theatlantic.com/ideas/archive/2020/03/whogets-hospital-bed/607807l.

Nancy, Jean-Luc. 1991. The Inoperative Community. Edited by Peter Connor. Translated by Peter Connor, Lisa Garbus, Michael Holland, and Simona Sawhney. Minneapolis: University of Minnesota.

Okimoto, Ruth Y. 2001. Sharing a Desert Home: Life on the Colorado River Indian Reservation, Poston, Arizona, 1942-1945. Berkeley, CA: Heyday Books. 
Orlowski, Jeff, dir. 2002. The Social Dilemma. 2020. Boulder, CO: Exposure Labs. Netflix.

Palumbo-Liu, David. 1999. Asian/American: Historical Crossings of a Racial Frontier. Palo Alto, CA: Stanford University Press.

Patel, Neel V. 2020. "Why the CDC Botched Its Coronavirus Testing." MIT Technology Review, March 5, 2020. https://www.technologyreview.com/2020/03/05/905484/whythe-cdc-botched-its-coronavirus-testingl.

PJS and JAM. 1947. "Report of Meeting of Adult Program Committee of Addison Terrace," February 19, 1947. Columbia University, Bureau of Applied Social Research Papers, MSo166, Box 08, Rare Book and Manuscript Library, Columbia University Library.

Rancaniello, Vincent, Dickson Despommier, Alan Dove, Rich Condit, Kathy Spindler, and Brianne Barker, hosts. 2020. "TWIV: 585: The Coronavirus Epidemic." In This Week in Virology (podcast), February 2, 2020. https://www.microbe.tv/twiv/twiv-585/.

Reinhard, Kenneth. 2005. "Toward a Political Theology of the Neighbor." In The Neighbor: Three Inquiries in Political Theology, edited by Slavoj Žižek, Eric L. Santner, and Kenneth Reinhard, 11-75 Chicago: University of Chicago Press.

Roethlisberger, Fritz Jules. 1941. Management and Morale. Cambridge, MA: Harvard University Press.

Roethlisberger, Fritz Jules, and William J. Dickson. 1939. Management and the Worker. Cambridge, MA: Harvard University Press.

Schmitt, Carl. 2007. The Concept of the Political. Expanded ed. Chicago: University of Chicago Press.

Shimakawa, Karen. 2002. National Abjection: The Asian American Body Onstage. Durham, NC: Duke University Press.

Sprunt, Barbara. 2021. "Congress Passes Bill to Counter the Rise in Anti-Asian Hate Crimes." NPR, May 18, 2021. https://www.npr.org/2021/05/18/997847571/congresspasses-bill-to-counter-the-rise-in-anti-asian-hate-crimes.

Stephens-Davidowitz, Seth. 2017. Everybody Lies: Big Data, New Data, and What the Internet Can Tell Us about Who We Really Are. New York: Dey St. Books.

Tang, Liang, Romer Rosales, Ajit Singh, and Deepak Agarwal. 2013. "Automatic Ad Format Selection via Contextual Bandits." 2013. CKIM '13: Proceedings of the 22nd ACM International Conference on Information \& Knowledge Management, October 27, 2013, 1587-94. https://doi.org/10.1145/2505515.2514700.

Wald, Priscilla. 2008. Contagious: Cultures, Carriers, and the Outbreak Narrative. Durham, NC: Duke University Press.

Wang, Yeming, Dingyu Zhang, Guanhua Du, Ronghui Du, Jianping Zhao, Yan Jin, Shouzhi Fu., et al. 2020. "Remdesivir in Adults with Severe COVID-19: A Randomised, Double-Blind, Placebo-Controlled, Multicentre Trial." The Lancet 395 (10236): 1569- 
78. https://www.thelancet.com/journals/lancet/article/PIIS0140-6736(20)31022g/fulltext.

Žižek, Slavoj. 2020. PANDEMIC!: COVID-19 Shakes the World. New York: OR Books.

\section{Author Bio}

Wendy Hui Kyong Chun is the Canada 150 Research Chair in New Media and Professor of Communication at Simon Fraser University, where she also directs the Digital Democracies Institute. She is author of numerous books and articles, including Discriminating Data: Correlation, Neighborhoods, and the New Politics of Recognition (MIT, 2021); Updating to Remain the Same: Habitual New Media (MIT, 2016); Programmed Visions: Software and Memory (MIT, 2011); and Control and Freedom: Power and Paranoia in the Age of Fiber Optics (MIT, 2006). 